\title{
The Dutch Colonial Economic Policy: Coffee Exploitation in Tapanuli Residency, 1849-1928
}

\author{
*BUDI AGUSTONO ${ }^{1}$ \\ JUNAIDI ${ }^{1,2}$ \\ ${ }^{1}$ Department of History, Faculty of Cultural Sciences, University of Sumatera Utara, \\ Medan, Indonesia \\ Current affiliation: \\ ${ }^{2}$ Department of History, Faculty of Cultural Sciences, University of Gadjah Mada, \\ Yogyakarta, Indonesia \\ *Corresponding author: budi.agustono@usu.ac.id
}

Published online: 26 September 2018

To cite this article: Agustono, B. and Junaidi. 2018. The Dutch colonial economic policy: Coffee exploitation in Tapanuli residency, 1849-1928. KEMANUSIAAN the Asian Journal of Humanities 25(2): 49-71, https://doi.org/10.21315/kajh2018.25.2.3

To link to this article: https://doi.org/10.21315/kajh2018.25.2.3

\begin{abstract}
The occupation of Tapanuli district was an objective of Dutch colonial settlement in the Indonesian archipelago. The expansion of the area was not only due to political factors but also due to vast economic ambition. This was evident from the trade monopoly of coffee from the beginning of Dutch occupation in the area. The colonial government's desire for the economy was gratified by the implementation of coffee forced-farming in Tapanuli. The forced-farming system created huge profits for the treasury of the Dutch colonial government. The colonial exploitation was not confined to coffee forced-farming only but also extended to the local people, who were forcibly exploited for their labour as coolies to carry the coffee beans from remote storehouses to the port. The suffering of the local people worsened when Tapanuli district was categorised as a taxpayer district by the end of 19 th century.
\end{abstract}

Keywords and phrases: coffee, cultivation, Dutch colonial, Tapanuli, tax

\section{Introduction}

For most developing countries, the agricultural sector is the primary foundation of the economic activity of the people. In Indonesia, politics and economy are dominated by the state, so the implementation of economic policies affects people's economic life. Careful observation suggests that the current economic policies of the Indonesian government are essentially an extension of Indonesia's (Netherland's Indies) past experiences. Therefore, the state remains the most 
powerful social-political group and is decisive in making economic policies that cause economic changes.

There are quite a number of current Indonesian economic structures which are influenced, even shaped, by the long history of economic experiences, particularly the political economy of the Dutch colonialists in the 19th century. The Dutch colonial economic policy, then known as the cultuurstelsel (the cultivation system), was a series of policies and the economic-political system of the Dutch colonial government, reflecting its efforts to make profits from agricultural commodities. The revenue from this economic sector was definitely an economic gain and was collected without entailing significant expenditures, as the colonial government was spending its capital mainly on land cultivation and had very cheap labour costs (Fasseur 1975, 41).

The experiences of the Dutch colonial government in managing the agricultural sector in Java influenced the expansion of that authority in the 19th century. It is known that the practice of cultuurstelsel in the Dutch East Indies was first implemented on Java in 1830 and that this practice was subsequently also implemented outside of Java. In fact, in Java, this practice had a powerful socioeconomic impact on the Javanese people in that era. The forced confiscation of land from native people and the extortion of labour confronted the Javanese with the dilemma of mass poverty (Geertz 1976, 54-87), and in turn, the citizens could not find opportunities to improve their quality of life (Van Niel 1972, 89-109).

The success of this cultivation system practice in Java was based on the colonial experiences during the era of the Vereenigde Oost-Indische Compagnie (VOC). The VOC had implemented a policy (Priangerstelsel) based on the principle of obtaining commodities by force from the cultivation of particular crops such as coffee in the areas that were directly under the VOC's control. The business of crop cultivation was first implemented in Java since this was also supported by the high demand from European markets (Bremen 2015).

Coffee production in Java in that era provided a great profit for the VOC. In the era of the Dutch colonial government, they attempted to apply the system that had been started by the VOC, and they not only created Java as one of the areas for cultivating coffee but also expanded such cultivation to Sumatra. The expansion of this policy also aimed at unifying the areas under colonial authority into a real political and economic unification under a country named "the Dutch East Indies" (McStocker 1987, 40-69). 
What happened in Java was slightly different from the practice of implementing the cultivation system in Tapanuli district. In this region, the economic policy used by the colonial government appeared in the form of gouvernements koffiecultuur (the cultivation of coffee possessed by the government). Fundamentally, that policy had the same objective, namely, "making the whole areas of Minangkabau and Tapanuli as the second Java". However, in Tapanuli district, this Dutch colonial policy did not cause as severe effects on the local people. At that time, if people felt oppressed by the regulations of cultuurstelsel, they could easily move to other forms of activity (because in this area, coffee was the only commodity required to be planted). In addition, people could be traders as an alternative if they could not farm.

\section{Tapanuli}

Geographically, the Tapanuli district of North Sumatra lies at $0^{\circ} 58^{\prime} 35^{\prime \prime}$ Northern latitude and between $98^{\circ} 42^{\prime} 50^{\prime \prime}$ and $99^{\circ} 34^{\prime} 16^{\prime \prime}$ Eastern longitude. Briefly, the area of Tapanuli is outlined by the Bukit Barisan mountain range. There are a number of famous hills and mountains, such as Lubuk Raya mountain, Sibual-buali mountain, Sorik Marapi mountain, Simpon mountain and Simago-mago hills (Osthoff 1851, 56).

The landscape of Tapanuli lies in the noordelijke afdeeling (northern area) of Gouvernement van Sumatra's Westkust (the Government of Sumatra's West Coast) administrative area. The administrative centre of the Dutch colonial government for the noordelijke afdeeling area was then located in Air Bangis. In addition to its role as administrative centre, Air Bangis also served as a port or entrance to Tapanuli district, although it was yet to be occupied by the colonial government at that time.

The Tapanuli district began to be occupied by the Dutch colonials in 1833 (Kielstra 1889, 313-338). In that year, the Netherlands' troops, led by Major Eiler, landed at the port of Natal and continued to invade the inland until they reached Pakantan and Mandailing. In Pakantan, Major Eiler set up a military base and made a pact with the kings of Mandailing. Before long, troops under the command of Colonel Elout reinforced the occupation of the Mandailing area and later built a fort known as Fort Elout. The building of the fort was to maintain stability within the occupied area of Mandailing and was also intended to be a military base for the colonials to launch an invasion of Fort Bonjol, which was ruled by clerics. In addition, Fort Elout also functioned as a fortress for the Dutch in their attempts to expand their occupancy to the Angkola and Sipirok areas (Kielstra 1888b, 299, 367; Kielstra $1889,314-322)$. 
The Tapanuli district, which was then occupied by the Dutch, covered only the Mandailing, Angkola and Sipirok areas, while Padang Lawas, Silindung and Toba were still free areas. The security of the three occupied areas was considered successfully controlled, and therefore, they were turned into direct bestuur gebied (local authority areas) of Air Bangis district and Sumatra West Coastland. To ensure the administrative stability of the new area, Eduard Douwes Dekker was appointed as the Resident Assistant of Natal-Mandailing, stationed in Natal. In 1838, the position of Resident Assistant of Natal was transferred to Panyabungan with the title Resident Assistant of Mandailing-Angkola. The Resident Assistants who assumed office, among others, were Th. J. Willer and A.P. Godon (Godon $1862,3-5)$.

In 1852, the borders of the Tapanuli district were as follows: on the northern part, it was adjacent to Trumon; on the eastern part, it was adjacent to Toba Besar areas such as Dairi, Pasaribu, Silindung, Toba and Padang Lawas; in the southern part, it was adjacent to afdeelingen of Air Bangis and Rao; and the western part was bounded by the Indian Ocean. The landscape of Tapanuli stretches from its southeast point to its northwest point, so it was suitable for the construction of a few major and minor ports along the coast of the district (Couperus 1855, 1).

The reorganisation of administrative authority in Gouvernement van Sumatra's Westkust in 1842 had upgraded the afdeeling of Mandailing-Angkola into Tapanuli Residency, while Air Bangis Residency was downgraded into an afdeeling of Air Bangis under the administration of Padangsche Benedenlanden. The first regent of Tapanuli Regency was L.A. Galle, who began to serve in the office in 1843 (Joustra 1926, 32).

The population of the afdeeling of Mandailing and Angkola then was 44,000, based on a census taken in September 1846. Mandailing Godang had 17,000; Mandailing Julu, 11,000; Ulu and Pakantan, 5,000; and Sipirok and Angkola, 11,000 (Freudenberg n.d., 20, 25).

Other Tapanuli areas that were still free were gradually occupied in the midst of the 19th century. Padang Lawas and Silindung were occupied in 1873, and Toba area in 1881. To control all of the occupied areas of Tapanuli, in 1884 the Dutch colonial government transferred the central administration to Padang Sidimpuan. However, in 1905, the central administration of Tapanuli Residency was re-transferred to Sibolga (Joustra 1926, 32) due to the reorganisation of the administrative government that took place that year, which stated that Tapanuli district was to be independent of Gouvernement van Sumatra's Westkust and that the chain of command was to come directly from Batavia. 
The above scenario depicted the political manoeuvres of the Dutch colonial government in subjugating the territory of Tapanuli. During these political manoeuvres, the Dutch engineered economic policies that could exploit huge gains from the newly subjected colony. One of the economic policies of the Dutch in Tapanuli was the exercise of plant cultivation policy or obligatory coffee submission to the government or, as it was known, Gouvernements Koffiecultuur.

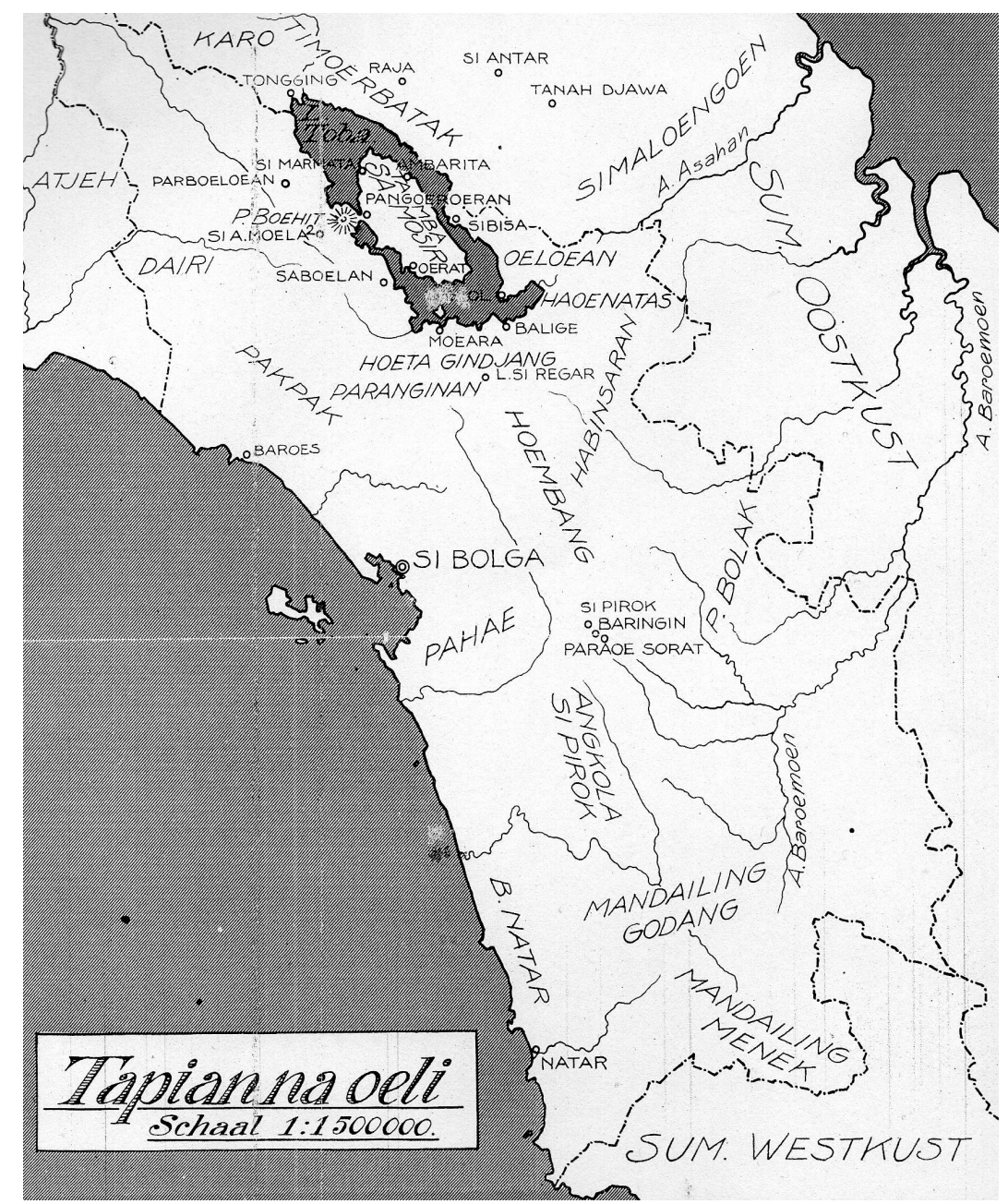

Figure 1. The map of Tapanuli Source: AS GB-MGS, No. 4060, ANRI 


\section{Pre-colonial}

Coffee is not an indigenous Indonesian commodity. This plant was initially introduced to Indonesia by the VOC at the end of the 17th century. During that time, the VOC was trying to cultivate coffee at several places in Java, primarily in the area around Priangan, West Java. The effort to farm coffee in Java was related to demand for the commodity in the European market (Asnan 2007, 203). To supply the annually growing demand for coffee, the VOC implemented a policy called Priangerstelsel, i.e., a principle to gather coffee crops by force within the subjugated areas that were under direct control of the VOC (Van den Berg 1879, 428).

Coffee plantations along the western Sumatra coastland (Minangkabau and Tapanuli) were perceived as initially being grown in the inland area, in the surroundings of Agam highlands, to be precise. From that area, the coffee plants spread to other Minangkabau areas as far as the Tapanuli districts, i.e., Pakantan area (Mandailing) and Sipirok (Angkola). The only coffee species known to the local people at first was Arabica (Earlier historians concluded that this kind of coffee most likely was brought by people returning home after completing their Hajj pilgrimage in Mecca.) (Dobbin 1992, 48-53, 265-267). Initially, the coffee seeds were not planted in an orderly manner but rather grew like briars that resembled a forest grove more than cultivated farming. Therefore, coffee plants then were often called "forest coffee" (Van Burst 1827, 65). The people of Mandailing and Angkola usually planted coffee close to their home villages. Because so many coffee plantations surrounded the village, a new term was coined for the coffee: fence coffee. It was so-called because the people's coffee plantations surrounded the village like a fence.

The existence of coffee in the inland of Minangkabau and Tapanuli prior to Dutch colonialism can be divided into two periods. First, there was the period of free trade in coffee from 1780 to 1883 . During this phase, local coffee trading could still take place freely without any obligatory involvement in a trading network run by the Dutch. Second, there was the period of 1833-1847, which was marked by the local coffee trading sector being gradually directed by the Dutch power quartered in Padang. During this phase, the coffee distribution sector began to be subjected to government regulations such as price protection and various kind of tax impositions, such as seaport taxes and market taxes (Zed 1983, 43-44).

In their daily life, the people of Mandailing and Angkola like coffee very much. Therefore, it is not surprising that coffee trading has taken place at local markets since long ago. The first information concerning coffee trading comes from the 
report of a Dutchman at the end of the 18th century. Among others, the report conveyed that coffee trading had spread from inland areas to the markets of Padang by 1789 . Coffee trading had not then become an export commodity; instead, it was just a trading commodity in local markets for household consumption (Dobbin 1992, 49-50). In 1790, a year after the first report of coffee trading, there came a second report about the first American ships that anchored in the area loading their cargos with coffee. Since that year, coffee has turned into one of the main export commodities from the area (Asnan 2007, 204).

Initially, the traded coffee was in the form of coffee leaves. They were sometimes sold fresh (fresh coffee leaves), but more often, they were in dried leaf form, which had been cooked in such a way (usually by drying it on top of cooking stoves) that it turned into leaves ready to be served in beverages (Hanbury 1854, 370-375; Zed 1983, 45-46). The tradition of using coffee leaves to make beverages had been well known among the people of Minangkabau and Tapanuli, especially among the elder generation in the area.

After the first anchoring of an American ship at Sumatra's west coast, which bought the coffee and provided a huge profit in its home country, additional American ships arrived continuously in the following years. In addition, by then, British merchant ships were also loading coffee that they bought from local people and shipped to Europe. This situation prevailed until the Dutch reoccupied Sumatra's west coast area in 1819, yet apart from Tapanuli, Air Bangis and Natal, which were the exit gates for commodities from Tapanuli's hinterland, much of the area was still under British occupation, at least until the end of 1825.

\section{Forced-farming}

Coffee was one of the most important commodities for the colonial government in Tapanuli. The colonial coffee economy had started when the Mandailing and Angkola areas began to be occupied in 1833. Colonial economic policy was then implemented in the area, i.e., a compulsory coffee submission system to the colonial government (Lulofs 1904, 1637).

Initially, the seeds for a coffee plantation in Tapanuli came from beans that were cultivated in Sipirok and Pakantan. One of the coffee plantation owners at that time was Djaroemahot Nasution. His coffee plantation covered the slopes of the Aek Bariba mountains up to the Bungabondar area. The plantation was inherited from his adoptive father, a salt trader who frequently went to the port. The coffee seeds were collected by Djaroemahot's adoptive father from Arabian traders who came to the west coast ports in those days (Sumatra's Westkust No. 127/11, ANRI). In 
addition to being the owner of the coffee plantation and a coffee farmer, Djaroemahot Nasution also dominated the coffee market in his time, which enabled him to build a connection with Gustaf van Asselt, a pakus (coffee-collecting merchant) who worked for the Dutch colonial government. In fact, these pakuses were also the "intelligence" of the Dutch and spied on the trade to help secure the interests of the Dutch in Tapanuli. These pakuses usually covered up their main action by also carrying out evangelism (Sumatra's Westkust No. 127/11, ANRI).

Information from van Asselt and the pakuses eventually became the reference for the colonial government to send Dr. Franz Junghuhn, an anthropologist and botanist. Junghuhn did his research from Mandailing to Sipirok, Angkola. The result of his research was a recommendation of the mountain range of Mandailing and Angkola as a good place for hardy plants such as coffee (Junghuhn 1847, 67).

As a result of the findings of Junghuhn, the Dutch colonial government started to think about establishing a coffee plantation in the Tapanuli area. To make the endeavour run smoothly and gain the support of the local people, the Dutch followed up on Junghuhn's research by sending Herman Neubronner van der Tuuk, a linguist, to study the language and culture of the Tapanuli community. The findings of van der Tuuk generalised languages in Tapanuli into one language category, i.e., the Batak Language (languages of Mandailing, Angkola and Toba) (Junghuhn 1847, 67).

Based on the research of Junghuhn and van der Tuuk, the Dutch colonial government finally set up coffee plantations in Mandailing and Angkola and applied the coffee forced-farming system to the local people. The implementation of government coffee cultivation, gouvernements koffiecultuur, better known as a forced-farming system, in Sumatra's west coast area had in fact been ongoing since 1847. The basic idea of the coffee forced-farming system was stated in the Decision Letter of Governor A.V. Michiels on 1 November 1847, which compelled every family to plant at least 150 trees of coffee. All coffee crops had to be yielded to the government's available storehouses. As compensation, the people would get paid in cash according to the price set by the government (Amran 1985, 98-99). Despite the commencing of the implementation in 1847, for Tapanuli, it was not executed until 1849 (Zed 1983, 88-89, 113-114).

The cultivation of coffee in Tapanuli was a political and economic policy of the central government to gain profit from the coffee agricultural sector of the area. Its implementation in Tapanuli was directly rejected by the local people because they perceived the initially agreed partnership scheme as being transformed into 
exploitation, causing it to trigger opposition and riots in several places. Despite the situation, the policy was still executed by the colonial government.

To secure the colonial government's programme in Tapanuli, Gubernur A.V. Michiels assigned Major Alexander van der Hart to assist him in the civil administration in Tapanuli. In performing his duty, he was successful in pacifying the social turmoil that took place at Mandailing and Angkola and in subduing the resistance of Tuanku Tambusai in Sosa and Dalu-Dalu. In providing security for the cultivation, the government stationed officers to guard those plantations and provided security escorts for coffee transportation to port storehouses in Natal and Sibolga (AS GB-MGS, No. 4233, ANRI).

Coffee cultivation in Sipirok started by enforced coffee planting by the locals on the mountain slopes and lowlands of the Aek Bariba mountain range. Coffee plantations in the area were initiated by van Asselt after he had succeeded in evangelizing the Parausorat residents, while the coffee plantations in the Bungabondar, Lancat and Simangambat areas were initiated by Pastor Beltz (Joustra 1926, 53).

To multiply coffee production in Tapanuli, in 1835, the Dutch colonial government imported Arabica coffee seeds from Java through the port of Natal. This coffee species later was planted in Pakantan and Sipirok. To support the government economic policy, in Tano Bato and Sipirok, coffee seeding farms were established in 1840 . The supply of coffee seeds from Tano Bato and Sipirok could finally fulfil the needs for coffee seeds and they were distributed to the Mandailing and Angkola areas, especially Pakantan and Sipirok. With the existence of coffee seeding farms in Tapanuli, the Dutch colonial government in Tapanuli did not have to request coffee seeds to be supplied from Java (Sumatra's Westkust No. 122/9, ANRI).

Coffee plantations in Mandailing produced 1,300 pikuls (a pikul is a shouldercarried load weighing approximately $62.5 \mathrm{~kg}$ ) in the year 1845 , and in 1846 it reached 3,000 pikuls. The estimated Mandailing coffee production in 1847 and 1848 was 5,000 pikuls and 10,000 pikuls, respectively. The production estimation for the next two years was derived from the audit result by the government in $1841-1843$ by calculating the number of coffee plants in every plantation (Kielstra 1888a, 28).

The Dutch colonial government started to buy coffee for the first time in 1845 . This purchase was of course from local coffee farmers. It was then kept in coffee storehouses. For Mandailing, the coffee storehouse was in Tano Bato, and for Ulu and Pakantan areas the storehouse was Kotanopan, while for the Angkola area, 
they were located in Padang Sidempuan, Sipirok and Sigalangan (Anonymous 1924, appendix 3).

The number of coffee plants in Mandailing and Angkola in 1848 had already reached 2,800,000 and had begun to yield crops. According to the description of A.P. Godon, who visited the Tano Bato coffee storehouses in May 1848, there were 4,100 pikuls of coffee in the storehouses; the amount was the coffee crops of both that year and the year before (1847). Then, at the beginning of January 1849, there had been further purchases of coffee that amounted to another 5,200 pikuls. Thus, altogether, there were 9,300 pikuls of coffee in the storehouses ready to be shipped to the port of Natal (Godon 1862, 9-11).

By the middle 1850s, there were 5,500,000 coffee plants scattered around the Mandailing (Mandailing Godang, Mandailing Julu and Pakantan), Angkola (Sipirok) and Batang Natal areas. Each household planted approximately 500 coffee plants, and the government set the coffee collection quarters in Natal and Air Bangis (Van der Hoeven 1864, 44). In 1856, the colonial government succeeded in collecting no less than 20,000 pikuls of coffee with a total revenue of $f 3,995.628$ (Godon 1862, 9-11; Kielstra 1888a, 65).

As described above, until the mid-19th century, the parts of Tapanuli district occupied by the Dutch covered only the Natal, Mandailing and Sipirok (Angkola) areas, while other areas, such as Padang Lawas, Silindung and Toba Inland, were later occupied in the post-mid-19th century. With the occupation of some new territories in Tapanuli, the Dutch colonial government invited consultants/scientists to give their advice and recommendations concerning the expansion of the coffee cultivation areas and the addition of officials in the area. The coffee plantation areas that were discussed by the consultants included Mandailing Julu, Ulu and Pakantan; Mandailing Godang and Batang Natal; Angkola; Sipirok; and Padang Lawas, Toba and Silindung (AS GB-MGS, No. 4060, ANRI).

One result of discussions by those scientific advisers was that the Padang Lawas area (except the part adjacent to Sipirok) was freed from coffee cultivation. The exception of this area was because it was a vast area of reeds completely unsuitable for coffee cultivation. Despite being freed from coffee cultivation, the residents of the area were still compelled to submit the fruits of the land to the government (AS GB-MGS, No. 4060, ANRI).

In addition to Padang Lawas, afdeeling Toba and Silindung were also fully freed from coffee cultivation (Staatsblad van Nederlandsch-Indie 1892, No. 249). This exemption was due to the area being a centre of rice production; thus, the 
colonial government encouraged the local practice of the people in managing and developing rice fields. The residents of Toba and Silindung began to be mobilised to cultivate coffee after their coffee culture had been abolished, so the development of people-produced coffee was strongly encouraged to increase the amount of coffee production, in addition to the production from both government coffee and private coffee plantations (AS GB-MGS, No. 4060, ANRI).

Unlike in Padang Lawas, Toba and Silindung, coffee planting in Aek Puli was compulsory, yet it was freed from the cultivation system. This condition made many people in Sipirok dissatisfied. In the Pahae area, the coffee planting was still compulsory (AS GB-MGS, No. 4060, ANRI).

In addition to deciding on unsuitable areas for coffee plantation, the scientific advisers also reached other conclusions for the Dutch colonial government. The content of their final conclusions was as follows: (1) land appropriation for coffee plantation, as much as possible, was not to be too great a distance from the borders of the plantation owners' houses, and the government was to continue monitoring the acceleration of cultivation; (2) the government should have appropriate reserve lands for the cultivation of other plants and for the needs of village expansion; and (3) the chiefs and entrepreneurs of the plantations had to create and execute one of the reasonable cultivation schemes. When such endeavours were undertaken, coffee cultivation would succeed and result in significant profits, which in turn would boost the eagerness of the people to plant coffee in their gardens and not make it difficult for the government and entrepreneurs who intended to rent their lands (AS GB-MGS, No. 4060, ANRI).

With their eagerness to increase coffee production, the Dutch colonial government had forgotten to make land appropriation for other plant cultivation, so much so that the production of other crops in the area became scarce. In addition, the government still imposed a very low coffee buying price in some areas, i.e., $f 15$ per pikul. The price was not enough to meet the livelihoods of the plantation owners at that time, as part of the revenue needed to be used for planting, caring for, and maintaining the plantation and for reaping, preparation and transportation (AS GB-MGS, No. 4060, ANRI).

Entering 1879, coffee production in Tapanuli suffered a downturn. The decrease in coffee production was triggered by the low coffee buying price set by the Dutch colonial government, which discouraged people from cultivating their coffee plantations. In 1871, there was a movement in Sibolga to support the eradication of the coffee cultivation system. These issues surrounding the eradication of the coffee cultivation system spread rapidly in Tapanuli so that the colonial government was 
eventually hard-pressed and pushed to dismiss the system. The revocation of the coffee cultivation law and the abolishment of obligatory coffee shipments did not take place evenly throughout Tapanuli. In some areas, such as Toba and Silindung, the obligatory coffee shipment was still applicable, and the regulation was even renewed on 20 November 1892 (AS GB-Bt, No. 130, ANRI).

The coffee production decline was also caused by the scarcity and limitation of good land for coffee in the areas of Sipirok, Pakantan, Mandailing Godang, Mandailing Julu and Batang Natal, causing the farmers to struggle to expand their plantations. In those areas, coffee plantations were generally near the settlements. Therefore, the government opened up forests that were a great distance from these settlements for the expansion of coffee plantations. Similar actions were taken in Toba because there was no more good land for coffee in the settlement area. It was only the residents of Sipirok who were willing to cultivate land far from their home villages. In Mandailing, the system was not implemented by the people due to their unwillingness to leave their villages (AS GB-MGS, No. 4060, ANRI).

The decline in coffee plantations was actually followed by a new programme of the government, i.e., the introduction of a taxation system in Tapanuli. The dissemination of a taxation system propagated by the colonial government was initially not well received. The local people then were still content with the end of the cultivation system; however, the coffee buying price set by the government started to increase. Therefore, farmers rushed back to cultivate their coffee plantations in line with the steadily increasing coffee buying price.

Once the people were freed from the coffee cultivation system, coffee production increased. Coffee production was 38 pikuls in 1884, 75 pikuls in 1885, 73 pikuls in 1886, 70 pikuls in 1887, 13 pikuls in 1888, 22 pikuls in 1889, 4 pikuls in 1890, 57 pikuls in 1891, 63 pikuls in 1892, 386 pikuls in 1893, 239 pikuls in 1894, \pm 210 pikuls in 1895, 226 pikuls in 1896, 351 pikuls in 1897, 644 pikuls in 1898 and 700 pikuls in 1899. This coffee production data are based on the coffee brought to the Sibolga storehouse. By making the areas of Toba and Silindung into obligatory coffee submission quarters, the colonial government targeted achieving coffee production above 110,000 pikuls (AS GB-MGS, No. 4060, ANRI).

The coffee-producing area in Tapanuli between 1894 and 1898 was still dominated by the Mandailing area rather than Angkola. Within those four years, coffee production in the Mandailing areas (i.e., Mandailing Godang) was 656 pikuls, and coffee production in Mandailing Julu and Pakantan was 2,950 pikuls, while Angkola produced coffee amounting to 162 pikuls for onderafdeeling Angkola and 2,169 pikuls for Sipirok. Batang Toru no longer produced coffee, and Padang 
Lawas was targeted to produce 36 pikuls per year. Coffee production in the Toba and Silindung areas from 1893 to 1898 averaged 343 pikuls per year, while the coffee export from this area in 1899 was more than 683 pikuls (AS GB-MGS, No. 4233, ANRI).

To increase coffee production in Tapanuli, the Dutch colonial government made a new economic policy of setting a minimum limit to the coffee obligatory submission for every area, set equally at $40 \%$. The reason was so that a coffee plantation owner could produce 1 pikul of coffee every harvest. The areas that were able to submit $40 \%$ of their coffee production to the government would be given special benefits, and the coffee buying price for the area would be increased every year. Nevertheless, not all of the areas were able to fulfil the demand of the government. For areas whose production did not meet the requirement of the government, the shortfall could be paid by cash equal to the value of the amount of the coffee below the $40 \%$ (AS GB-MGS, No. 4233, ANRI).

From Table 1, it can be seen that coffee production up to the year 1900 was still dominated by the Mandailing areas. Coffee production from the Angkola areas was always ranked second after Mandailing, while coffee production from the Padang Lawas area was the lowest, largely because the land condition of the area was unsuitable for coffee plants.

In the earlier years of the 20th century, the production of government coffee kept decreasing. There were several factors causing this downturn, one of which was the fairly high tax imposed on the coffee product, so much so that many local people left their coffee plantations unattended. From the end of the 19th century up to the beginning of the 20th century, the problem on Sumatra's west coast was indeed triggered by the imposition of taxes. Discussion about the tax issue will not be addressed here due to the different context of the problem.

In addition to the taxation problem, the government also could not control the free trade between the local people and outside merchants beyond the Dutch areas of Natal, Air Bangis and the east coast ports of Sumatra. The coffee free trading was termed "illegal coffee" by the colonial records. The rampant free trade meant most coffee did not end up in the government storehouses. As a consequence, the government coffee production decreased further, while the profit from illegal coffee trading flowed into the people's pockets (Zed 1983, 173-174). 
Table 1. Value of coffee production per region in Tapanuli for the year 1898-1900

\begin{tabular}{|c|c|c|c|c|c|}
\hline & \multirow{2}{*}{ Kuria } & \multirow{2}{*}{$\begin{array}{c}\text { Cultivation } \\
\text { payment } \\
\text { amount }\end{array}$} & \multicolumn{3}{|c|}{ Coffee production for the last 3 years } \\
\hline & & & 1898 & 1899 & 1900 \\
\hline \multirow{11}{*}{$\begin{array}{l}\text { Ond. Afd. } \\
\text { Angkola }\end{array}$} & Batunadua & 1,422 & 121 pikuls & 75 pikuls & 110 pikuls \\
\hline & Huta Rimbaru & 733 & 104 pikuls & 29 pikuls & 14 pikuls \\
\hline & Simapil Apil & 167 & 16 pikuls & 2 pikuls & 2 pikuls \\
\hline & Sabungan & 205 & 11 pikuls & 2 pikuls & 1 pikuls \\
\hline & Losung Batu & 855 & 8 pikuls & 3 pikuls & 3 pikuls \\
\hline & Sigalangan & 136 & 5 pikuls & 3 pikuls & 4 pikuls \\
\hline & Surumatinggi & 150 & 4 pikuls & 15 pikuls & 12 pikuls \\
\hline & Muara Tais & 97 & 4 pikuls & 6 pikuls & 6 pikuls \\
\hline & Pintu Padang & 184 & 3 pikuls & 18 pikuls & 31 pikuls \\
\hline & Pijor Koling & 127 & 1 pikul & 3 pikuls & 4 pikuls \\
\hline & Siondop & 31 & - & - & - \\
\hline \multirow{10}{*}{$\begin{array}{l}\text { Ond. Afd. } \\
\text { Mandailing } \\
\text { Julu and } \\
\text { Pekantan }\end{array}$} & $\begin{array}{l}\text { Pakantan } \\
\text { Lombang }\end{array}$ & 364 & 1,105 pikuls & 989 pikuls & 1,064 pikuls \\
\hline & Manambin & 1,194 & 685 pikuls & 553 pikuls & 641 pikuls \\
\hline & Pakantan Dolok & 236 & 576 pikuls & 545 pikuls & 502 pikuls \\
\hline & Tamiang & 675 & 263 pikuls & 145 pikuls & 190 pikuls \\
\hline & Batang Gadis & 477 & 160 pikuls & 149 pikuls & 137 pikuls \\
\hline & Tambangan & 458 & 56 pikuls & 33 pikuls & 15 pikuls \\
\hline & Singengu & 191 & 42 pikuls & 10 pikuls & 2 pikuls \\
\hline & Panjanget & 108 & 27 pikuls & 50 pikuls & 33 pikuls \\
\hline & Sayur Matinggi & 130 & 12 pikuls & 4 pikuls & 1 pikul \\
\hline & Pasar Kotanopan & 28 & 1 pikul & - & - \\
\hline \multirow{8}{*}{$\begin{array}{l}\text { Ond. Afd. } \\
\text { Mandailing } \\
\text { Godang and } \\
\text { Batang Natal }\end{array}$} & Gunung Baringin & 567 & 213 pikuls & 367 pikuls & 171 pikuls \\
\hline & Panyabungan & 923 & 64 pikuls & 74 pikuls & 74 pikuls \\
\hline & Maga & 338 & 95 pikuls & 52 pikuls & 46 pikuls \\
\hline & Gunung Tua & 546 & 82 pikuls & 45 pikuls & 61 pikuls \\
\hline & Pidoli Bukit & 654 & 59 pikuls & 52 pikuls & 57 pikuls \\
\hline & Huta Siantar & 449 & 38 pikuls & 22 pikuls & 14 pikuls \\
\hline & $\begin{array}{l}\text { Panyabungan } \\
\text { Julu }\end{array}$ & 273 & 27 pikuls & 46 pikuls & 52 pikuls \\
\hline & $\begin{array}{l}\text { Pasar } \\
\text { Panyabungan }\end{array}$ & 169 & 27 pikuls & 12 pikuls & 23 pikuls \\
\hline
\end{tabular}


Table 1. (continued)

\begin{tabular}{|c|c|c|c|c|c|}
\hline & \multirow{2}{*}{ Kuria } & \multirow{2}{*}{$\begin{array}{c}\text { Cultivation } \\
\text { payment } \\
\text { amount }\end{array}$} & \multicolumn{3}{|c|}{ Coffee production for the last 3 years } \\
\hline & & & 1898 & 1899 & 1900 \\
\hline \multirow{6}{*}{$\begin{array}{l}\text { Ond. Afd. } \\
\text { Sipirok }\end{array}$} & Muara Soma & 142 & 2 pikuls & 4 pikuls & 3 pikuls \\
\hline & $\begin{array}{l}\text { Muara } \\
\text { Parlampungan }\end{array}$ & 104 & 1 pikul & - & 4 pikuls \\
\hline & Sipirok & 1,495 & 1003 pikuls & 774 pikuls & 890 pikuls \\
\hline & Baringin & 794 & 689 pikuls & 596 pikuls & 718 pikuls \\
\hline & Parau Sorat & 312 & 120 pikuls & 91 pikuls & 118 pikuls \\
\hline & Simangambat & 193 & 24 pikuls & 8 pikuls & 11 pikuls \\
\hline \multirow{4}{*}{$\begin{array}{l}\text { Ond. Afd. } \\
\text { Batang Toru }\end{array}$} & Silantom & 79 & 2 pikuls & 1 pikul & 2 pikuls \\
\hline & Huraba & 64 & 44 last & 58 last & 50 last \\
\hline & Marancar & 64 & $1 / 2$ last & 23 last & 53 last \\
\hline & Sianggunan & 32 & - & - & - \\
\hline \multirow{9}{*}{$\begin{array}{l}\text { Ond. Afd. } \\
\text { Padang Lawas }\end{array}$} & Tano Rambe & 173 & 18 last & 15 last & 55 last \\
\hline & Hulu Batang Pane & 100 & 18 last & 9 last & 45 last \\
\hline & $\begin{array}{l}\text { Tapus Tano } \\
\text { Rambe Holbung }\end{array}$ & 174 & 10 last & 13 last & 23 last \\
\hline & Tolang & 50 & 3 last & 1 last & 6 last \\
\hline & $\begin{array}{l}\text { Napa Gadung } \\
\text { Laut }\end{array}$ & 72 & 2 last & 4 last & 4 last \\
\hline & Gulangan & 68 & 2 last & 3 last & 6 last \\
\hline & $\begin{array}{l}\text { Sandean } \\
\text { Pangikiran }\end{array}$ & 57 & - & 1 last & 1 last \\
\hline & Hulu Bilah & 110 & - & - & - \\
\hline & Hajoran & 204 & - & 2 last & - \\
\hline
\end{tabular}

Source: AS GB-MGS No. 4233, ANRI

In 1908, the coffee cultivation system and obligatory coffee submission to the government system were officially ended (Zed 1983, 215). After the eradication of this government economic policy, the coffee buying price in Tapanuli increased all the more. The ongoing problem that had gripped coffee farmers due to the price monopoly of the colonial government started to dissolve. The coffee plantations of the local farmers and the private sector revived and increased, so coffee from Tapanuli brought to Natal and Sibolga became steadily available from year to year to be later shipped to Padang for the auction process. During those days, the local farmers produced not only Arabica coffee but also coffee species such as Robusta 
and Liberia, which began to be planted at coffee plantations in the Tapanuli area (Anonymous 1924, appendix 3). Coffee production from Tapanuli continued to be an export commodity of the colonial government at least until 1928. In that year, many coffee plantations in Tapanuli were planted with other agricultural plantation crops such as rubber (Gijselman and Steup 1929).

\section{Coffee Transportation}

In the previous discussion, the coffee management system and the production level of the colonial government in Tapanuli was described. All coffee produced in the Tapanuli area was kept in coffee storehouses of the colonial government that were established in every area. From these storehouses, coffee was then transported to storehouses in the port of Natal and Djaga-Djaga (later Sibolga). The transportation and management of coffee in the Tapanuli area were under the charge of the toekang-kopie, meaning coffee specialist (Missive Resident van Tapanoeli, 5 December 1877, No. 3743).

From the coffee storehouses listed in the table, coffee was transported to the port of Natal and Djaga-Djaga (which later became Sibolga) and later forwarded to Padang. There were two means of coffee transportation, namely, by land and sea (Asnan 2007,103 ). The first means of transportation took several footpath segments (prior to the road construction) that connected the scattered storehouses in Mandailing and Angkola to the port of Natal. The distance between Tano Bato and Natal was approximately 50 pals (a pal is a distance marking stone of approximately $1.5 \mathrm{~km}$ ) with foot trails passing through the mountain range at approximately 4,000 feet above sea level. The hardest and narrowest path was the one between Kotanopan and Muara Sipongi (Van der Hoeven 1864, 12).

The means of coffee transportation then used human porters as "carrying coolies" and a few workhorses. The coolies were local people who were forced to work for the coffee transportation company. To provide this coolie force, the colonial government built a system using village chiefs. Every village was integrated with the purpose of accelerating the transportation of coffee. From Pakantan to Kotanopan and from Tano Bato to Tapus, coffee was carried by groups of coolies, and from Tapus to Natal, coffee was carried by a different group of coolies. From Pakantan to Kotanopan alone, it took two days, and those coolies were forced to work unceasingly for more than two months under military enforcement. There was no certainty concerning their wages. Only on the route from Tano Bato to Natal was a separate carrier wage given. The colonial government had actually allocated funds that were entrusted to the coolie council (comprising all the village chiefs) for 25 cents per day as a coolie wage. Nevertheless, those coolies only 
received wages of 15 cents a day. Therefore, it was very obvious that the coolies of Mandailing and Angkola had to endure hardship at that time. The transportation of coffee by coolies was part of the forced-farming system that was then applied by the colonial government (Godon 1862, 23-30).

The suffering of the Mandailing and Angkola residents who were bound as carrying coolies gradually contributed to social turmoil in the community. Many youngsters left their home villages to avoid being made a carrying coolie. Mostly they migrated to Sumatra's east coast, particularly to Padang Lawas and Medan. This situation caused the supply of coolies in every village to continuously drop. The Dutch colonial government was worried about the lack of the supply of coolies to carry the coffee to the ports. Deeming the situation to be growing worse, the Resident Assistant of Mandailing Angkola, A.P. Godon, suggested speedily opening and expanding the roads so that they could be passed by carts pulled by buffalos and workhorses. Prior to that, there were three alternative routes established in 1841, i.e., Tano Bato to Natal, Batang Gadis stream to Singkuang, and Muara Sipongi to Air Bangis. The chosen route was usually Tano Bato to Natal, as it was commonly used by traders and coolies. The route down the Batang Gadis stream to Singkuang was not suitable because it could not take the ship tonnage at the estuary of Batang Gadis and because the route of Air Bangis was too far (Godon 1862, 23-30).

Table 2. Coffee storehouses in Tapanuli

\begin{tabular}{lcc}
\hline Storehouse name & $\begin{array}{c}\text { Storage capacity } \\
\text { (in pikuls) }\end{array}$ & $\begin{array}{c}\text { Average coffee amount annually } \\
\text { (in pikuls) }\end{array}$ \\
\hline Panyabungan & 3,650 & 110 \\
Si Aboe & 1,100 & 10 \\
Gunung Baringin & 1,047 & 570 \\
Tano Bato & 475 & 250 \\
Muara Sama & unknown & 10 \\
Kota Nopan & 4,000 & 520 \\
Laru & 775 & 310 \\
Tolang & 1,109 & 470 \\
Muara Sipongi & 2,250 & 1,100 \\
Pekantan & 912 & 1,700 \\
Kota Gedang & 475 & 770 \\
Maga & 200 & 380 \\
Surumatinggi & unknown & 20 \\
\hline
\end{tabular}

Source: AS GB-Bt No. 130, ANRI 
Coffee transportation in Mandailing (Tano Bato to Natal) had already used carts pulled by workhorses, while coffee transportation in Angkola (Sipirok to Padang Sidempuan to Lumut) still used carrying coolies. From Lumut, the coffee was loaded on boats proceeding down river to Djaga-Djaga port due to the difficult access to Sibolga. Prior to coffee forced-farming, the trade road from Sipirok to Sibolga did not pass Padang Sidempuan but passed through Bulu Mario and Marancar (Sumatra's Westkust No. 127/11, ANRI).

In 1849, a post road and a bridge were constructed in Mandailing. The Rambin bridge at Batang Gadis river was replaced by a wooden bridge with a fibre roof so that coffee carts pulled by buffalos or workhorses could pass. Therefore, the coolie force in Mandailing started to be reduced and was gradually abolished. Nevertheless, things were different in Angkola, where coffee transportation still used coolies until the Batang Toru bridge was built in 1882. When the bridge was built, coffee transportation in Angkola began to use carts and workhorses to Sibolga. In conjunction with the establishment of Padang Sidempuan as the headquarters of the colonial government in 1884, the coffee transportation route which was previously from Tano Bato to Natal shifted to being via Muara Sipongi, Kotanopan and Panyabungan, Padang Sidempuan and was then forwarded to Sibolga. In 1886, the colonial government regulated that all coffee in Mandailing and Angkola had to be shipped to Sibolga. Consequently, trading activities at the port of Natal gradually decreased (Anonymous 1886, 19-22). Nevertheless, both in Natal and Djaga-Djaga, coffee transportation continued to Padang via sea transportation (Van der Hoeven 1864, 12).

Table 3. Coffee exports from Sibolga to Padang in the years 1913-1922 (in koyan)

\begin{tabular}{lcccccccccc}
\hline \multirow{2}{*}{ Type } & \multicolumn{10}{c}{ Coffee export per year } \\
\cline { 2 - 11 } & $\mathbf{1 9 1 3}$ & $\mathbf{1 9 1 4}$ & $\mathbf{1 9 1 5}$ & $\mathbf{1 9 1 6}$ & $\mathbf{1 9 1 7}$ & $\mathbf{1 9 1 8}$ & $\mathbf{1 9 1 9}$ & $\mathbf{1 9 2 0}$ & $\mathbf{1 9 2 1}$ & $\mathbf{1 9 2 2}$ \\
\hline Robusta & - & 50.603 & 90.890 & 82.131 & 15.623 & - & 402.152 & 31.701 & 169.277 & 963.624 \\
Liberia & 22.891 & - & - & - & - & - & - & - & - & - \\
Others & 31.437 & 24.890 & - & 87.1888 & - & - & 78.541 & 38.821 & 2.889 & 12.667 \\
\hline
\end{tabular}

Note: 1 koyan $=40$ pikuls $=800$ gantang $=2,470.4$ kilogram

Source: Anonymous (1924)

In Tapanuli district, there was a body organising coffee buying/collecting trader activities that worked for the colonial government. This body was called pakus. The famous pakus chairman in Mandailing and Angkola then was Gustaf van Asselt (Godon 1862, 15).

Some of the rights for coffee transportation in Tapanuli district, apart from being retained by the government, were also given to the private sector. Coffee 
transportation rights from the Mandailing area to Natal were given to W. Townsend. He was a trasportannemers. He transported coffee with carts and workhorses from Mandailing to Natal and from Natal to Padang using boats and ships (Sumatra's Westkust No. 152/1, ANRI). In addition to Townsend, there were many other trasportannemers residing in Tapanuli. Their dwellings were scattered in Air Bangis, Natal, Sibolga and Padang Sidempuan. In Padang Sidempuan, there were 56 Chinese and 5 other Eastern foreigners, and in Sibolga, there were 252 Chinese and 25 other Eastern foreigners (AS GB-TZG No. 6327, ANRI). In addition to owning carts and workhorses as the means of transportation to the ports, these trasportannemers also owned ships to ship coffee from Tapanuli ports to Padang.

In Padang, the coffee coming from Tapanuli was then auctioned off together with other coffees produced from the Minangkabau areas. In 1905, the government held a coffee auction in Padang. At the auction, the coffee from Tapanuli totalled 200 pikuls of Mandailing coffee and 200 pikuls of Angkola coffee (AS GB-Bt No. 1186, ANRI). In the following years, coffee production from Tapanuli kept increasing, and this was also coupled with an increase in the offering price for the Tapanuli coffee.

In 1925, the statistics bureau office recorded that coffee exports from the Tapanuli area amounted to 1,828 tonnes. The following year, fresh coffee produced from the Mandailing area amounted to 1,620 pikuls with an offering price of $\pm f 72$, while the fresh coffee from Angkola amounted to 650 pikuls with an offering price of $\pm f 68$. The coffee produced from the Mandailing area amounted to 200 pikuls with an offering price of $\pm f 77$, and the amount of coffee from Angkola was the same as that from Mandailing, i.e., 200 pikuls, but had an offering price lower by 1 point than the price of Mandailing coffee, i.e., $\pm f 69$ (Department van Landbouw 1926).

At the coffee auctions in Padang, Mandailing coffee always received the highest bids, and Angkola coffee was a rank below, followed by a steady coffee supply from the northern parts, such as from Air Bangis, Rao and Lubuk Sikaping. The best coffee plantation crops of the Mandailing and Angkola areas were coffees from Pakantan and Sipirok. The highest bidding price that was ever been offered for Mandailing coffee in 1922 was $f 87,50$ to $f$ 92, and that for Angkola coffee was between $f 87$ and $f 90$ (Anonymous 1924, appendix 13).

The high quality of Mandailing and Angkola coffees had made them distinct, and they were given a distinct label during the auction in Padang since 1921. The purpose was to ensure that they would not get mixed up with coffees from other areas. The label attached to both coffees corresponded to their place of origin, i.e., "Mandailing Coffee" and "Angkola Coffee" (Anonymous 1924, 7). 
Nonetheless, the colonial government was troubled by fraud, which later was to be a frequent occurrence. For instance, coffee from Tanah Datar was brought to Lubuk Sikaping and forwarded to Air Bangis and port of Natal. The intention and the goal were to get those coffees tagged with a higher price when they were shipped to Padang due to the perception that they originated from Mandailing and Angkola or from other Tapanuli inland areas (Anonymous 1909, 1084-1085).

Coffee production from Tapanuli kept declining as the years went by. In 1928, the last coffee plantation of the government in Tapanuli was finally changed into a rubber plantation. This coffee plantation was owned by Rotterdam Tapanoeli Cult. Mij Rott. with the plantation located at Marpinggan and Marancar (Gijselman and Steup 1920, 1927, 1929). Nevertheless, the Tapanuli coffee originally from Mandailing and Angkola areas still exists even today, thanks to the village coffee plantations that are still being cultivated.

\section{Conclusion}

In general, this research intended to trace the history of coffee production in Tapanuli from the perspective of Dutch colonial economic changes. The change emphasised in this case was the colonial policy as applied to coffee from the 19th century until the 20th century, specifically in 1849-1928. That policy was implemented in the cultuurstelsel of coffee, which, at the peak of its development, contributed significant foreign exchange to the government's treasury.

As outlined earlier, the implementation of coffee cultivation in Tapanuli was a political-economic policy of the central government for exploiting the profits of the agricultural coffee commodity products in that area. The case of Tapanuli was definitely not much different from the cases of Java and West Sumatra in terms of its organisation of coffee cultivation and the response of its citizens. In Tapanuli, the application of that policy encountered opposition from local people because the scheme of cooperation that had been agreed upon in the beginning had shifted in its implementation to become exploitation, according to the local people. Nonetheless, in fact, the colonial government was never deterred and implemented that policy nonetheless.

The development of coffee cultivation in Tapanuli, as well as in Java and West Sumatra, starting in 1849 was a part of the form of colonial government exploitation to obtain high profits. This policy forced local people to plant coffee and provided the products of coffee to the colonial government. In other words, the government had monopolised people's economy in Tapanuli. Moreover, people who did not have any lands for coffee cultivation were forced to work as porters of coffee to 
carry the products of coffee from the storage centres of coffee distributed in the remote areas in Tapanuli to the harbours in the coast of Air Bangis, Natal and Djaga-Djaga.

This cultivation system policy implemented by the government eventually ended in the 1880s. Nevertheless, several areas in Tapanuli, such as Mandailing and Angkola, still implemented the mandatory system of obtaining coffee products from local people and providing them to the government. After this system of coffee cultivation was dismantled, again, the colonial government made economic policies that kept people suffering. This government policy was an application of a tax system throughout all areas of the west coast in Sumatra.

The legacy of colonial policies applied by the Dutch until today is the labelling or the trademarking of Mandailing and Angkola coffee due to its high quality compared with that of coffee from other areas in Nusantara at that time. The quality of coffee from those two regions of Tapanuli had gained international market recognition due to its excellent quality and unique flavour sensation. Today, Mandailing and Angkola coffee still receives recognition and a position in the international market.

Over such a long period, the implementation of the coffee cultivation system had its ups and downs along with the fluctuations of coffee production, which tended to decrease in the last quarter of the 19th century. In addition, the government also conducted experiments with tax implementation. Based on the analysis above, this research traces the political-economic history in the Tapanuli district and emphasises the socio-economic changes of its population.

\section{References}

Amran, R. 1985. Sumatra Barat plakat panjang. Jakarta: Penerbit Sinar Harapan. Anonymous. 1886. De Gids. Jaargang 50. Amsterdam: P.N. van Kampen \& Zoon. Anonymous. 1887. De bevolking en productie der Padangsche bovenlanden. IG (Indische Gids) 9(I).

Anonymous. 1909. Geknoei met Sumatra-koffie. IG (Indische Gids) 31(II): 1064-1065. Anonymous. 1924. Koffie eenige bijzonderheden over cultuur, breiding productie uitvoer en handel: met een maarktoverzight over de jaren 1911-1923. n.p.: n.pub.

AS GB-Bt (Algemeene Secretarie Seri Grote Bundel Besluit 1891-1942). No. 130. Arsip Nasional Republik Indonesia (ANRI). . No. 1186. Arsip Nasional Republik Indonesia (ANRI).

AS GB-MGS (Algemeene Secretarie Seri Grote Bundel Missive Gouvernements Secretaris 1890-1842). No. 4233. Arsip Nasional Republik Indonesia (ANRI). . No. 4060. Arsip Nasional Republik Indonesia (ANRI). 
AS GB-TZG (Algemeene Secretarie Seri Grote Bundel Ter Zijde Gelegde Agenda 18911942). No. 6327. Arsip Nasional Republik Indonesia (ANRI).

Asnan, G. 2007. Dunia maritim pantai barat Sumatera. Jogjakarta: Ombak.

Bremen, J. 2015. Mobilizing labour for the global coffee market: Profits from an unfree work regime in colonial Java. Amsterdam: Amsterdam University Press. https://doi. org/10.26530/OAPEN_597440

Couperus, P. Th. 1855. De residentie Tapanoeli (Sumatra's Westkust) in 1852. TBG (IV): $1-41$.

Departemen van Landbouw. 1926. Nijverheid en handel afdeeling landbouw, een en ander de bevolkings cultuur van robusta koffie ter Sumatra's West-Kust en in Palembang. Weltevreden: Landsdrukkerij.

Dobbin, C. 1992. Kebangkitan Islam dalam ekonomi petani yang sedang berubah, Sumatera Tengah, 1784-1847. Jakarta: Indonesian-Netherlands Co-operation in Islamic Studies (INIS).

Fasseur, C. 1975. Kultuurstelsel en koloniaal baten, de Nederlandsche exploitatie van Java 1840-1860. Leiden: Universitaire Pers Leiden.

Freudenberg, R. n.d. Onder de Bataks op West-Sumatra. n.p.: n.pub.

Geertz, C. 1976. Involusi pertanian: Proses perubahan ekologi di Indonesia. Jakarta: Bathara.

Gijselman and Steup. 1920. Koffie-statistiek voor Nederlandsch-Indie. Batavia: n.pub. . 1927. Koffie-statistiek voor Nederlandsch-Indie. Batavia: n.pub. . 1929. Koffie-statistiek voor Nederlandsch-Indie. Batavia: n.pub.

Godon, A.P. 1862. De assistant-residentie Mandaheling en Angkola, op Sumatra's Westkust van 1847-1857, TNI (Tijdschrif voor Nederlandsch Indie) (I): 24.

Hanbury, D. 1854. Over het Gebruik der Koffijbladen op Sumatra. NTvNI (Natuurkundig Tijdschrift voor Nederlandsch-Indië) (3).

Joustra, M. 1926. Batakspiegel. Leiden: S.C. van Dunsburg.

Junghuhn, F. 1847. Die Battalander auf Sumatra. Berlin: G. Reimer.

Kielstra, E.B. 1888a. De koffiecultuur ter Westkust van Sumatra. Leiden: E.J. Brill. . 1888b. Sumatra's Westkust van 1826-1832. BKI, Deel 37b. 1889. Sumatra's Westkust van 1833-1835. BKI, Deel 38b.

Lulofs, C. 1904. Koffiecultuur en Belasting ter Sumatra’s Westkust”, IG, 26, (II).

McStocker, R. 1987. The Indonesian coffee industry. Bulletin of Indonesian Economic Studies 23(1): 46-69. https://doi.org/10.1080/00074918712331335121

Missive Resident van Tapanoeli. 5 December 1877. No. 3743. Arsip Nasional Republik Indonesia (ANRI).

Osthoff, H.L. 1851. Topograpische Scetsen van Sumatra. Batavia: n.pub.

Sweerts. 1892. Staatsblad van Nederlandsch-Indie 1892 (No. 249). Batavia: Landsdrukkerij.

Sumatra's Westkust No. 122/9. Politieke Verslag van Tapanoeli, 1861. Arsip Nasional Republik Indonesia (ANRI).

Sumatra's Westkust No. 127/11. Administratief Verslag van Tapanoeli, 1860. Arsip Nasional Republik Indonesia (ANRI).

Sumatra's Westkust No. 152/1. Maandrapporten 1853. Arsip Nasional Republik Indonesia (ANRI). 
Van Burst, H.G.N. 1827. Brieven over Bencoolen, Padang, het Rijk van Minangkabau, Rhiouw, Sincapoera en Poelo Pinang. Breda: F.B. Hoolingerus Pijpers.

Van den Berg, N.P. 1879. Historisch Statistische Anteekeningen over de Voortbrenging en Verbruik van Koffie. TNLNI (Tijdschrift van Nijverheid en Landbouw in Nederlandsch-Indie), xxiv.

Van der Hoeven, A. P. 1864. Een Woord over Sumatra: Deel II Sumatra's Westkust en Palembang. Rotterdam: H. Nijgh.

Van Niel, R. 1972. Measurement of change under the cultivation system in Java 18371851. Jurnal Indonesia (vol. 14, October 1972). New York: Cornell Southeast Asia Program.

Zed, M. 1983. Melayu kopi daun: Eksploitasi kolonial dalam sistem tanam paksa kopi di Minangkabau Sumatera Barat (1847-1908). PhD dissertation, Universitas Indonesia, Jakarta, Indonesia. 